\title{
*Innate and Discretionary Accruals Quality and Corporate Governance
}

\author{
Pamela Kent* \\ James Routledge* \\ Jenny Stewart** \\ * School of Business, Bond University \\ ** Griffith Business School, Griffith University
}

Acknowledgements: The authors acknowledge with thanks the helpful comments of Mike Bradbury the deputy editor, two anonymous referees, Rashad Abdel-khalik, Peter Baxter, Jere Francis, David Gadenne, Kathleen Herbohn, Leeanne Hodgson, Janice Hollindale, Alan Kilgore, Majella Percy, Farshid Navissi, Tony Tinker and workshop participants from the University of the Sunshine Coast, the Annual Conference of the Accounting and Finance Association of Australia and New Zealand, Sydney, July, 2008 and World Accounting Frontiers Series, University of Macau, July, 2009.

Corresponding Author:

Pamela Kent

C/- School of Business

Bond University

Gold Coast Qld 4229

Tel. 0755952279

Fax. 075595160

pkent@bond.edu.au 


\section{Innate and Discretionary Accruals Quality and Corporate Governance}

Abstract: This paper extends previous research on the association between corporate governance mechanisms and accruals quality. We derive measures of the discretionary and innate components of accruals quality and regress them against corporate governance characteristics. For discretionary accruals, we find use of a Big 4 audit firm and a larger audit committee are the primary governance mechanisms associated with higher accruals quality. For innate accruals quality, we find higher quality is associated with an independent board of directors, a larger, more independent and more active audit committee, and use of a Big 4 audit firm. Our findings suggest a stronger relation between sound governance mechanisms and innate accruals quality than discretionary accruals quality. 


\section{Introduction}

The association between corporate governance mechanisms and the quality of reported earnings has been the subject of a substantial body of research. Prior earnings quality research has highlighted the important role played by corporate governance in reducing the likelihood of intentional earnings management resulting from manipulation of accruals (Dechow et al., 1995; Klein 2002; Davidson et al., 2005; Koh et al., 2007). However, intentional earnings management is not the only source of accruals estimation error. Environmental uncertainty experienced by those making accruals estimations has also been shown to be an important source of error (Francis et al., 2005; Dechow and Dichev, 2002). Given that both sources of accruals estimation error have negative consequences on financial reporting quality, it is important to understand whether and how they can be mitigated by sound governance. Accordingly, the objective of this study is to assess the relation between governance mechanisms and accruals estimation error arising from the manipulation of discretionary accruals and from environmental uncertainty.

The study makes several important contributions. A key contribution relates to the use of the accruals quality measurement technique devised by Dechow and Dichev (2002) (hereafter referred to as 'DD'). The DD model measures accruals quality by examining the extent to which working capital accruals estimate realised operating cash flows. Our use of the DD model for determining accruals quality is a different approach to that used extensively in the prior literature. Previous studies have generally used the Jones (1991) model and its variants (Bartov et al., 2000; Davidson et al., 2005; Koh et al., 2007). ${ }^{1}$ A criticism of the Jones model is that it measures accruals quality in an indirect manner (Francis et al., 2005; Schipper and Vincent, 2003). The DD approach overcomes this problem by using an empirical model that

\footnotetext{
${ }^{1}$ See, for example, the 'modified Jones model' developed by Dechow et al. (1995).
} 
more directly measures accruals quality. Aboody et al., (2005, p. 653) note that the DD measure ‘is a relatively more direct measure of a company's information environment derived from fundamental accounting data contained in its financial statements.' In this regard, our study provides a useful point of comparison for prior earnings management studies.

Use of the DD model to determine accruals quality also enables us to examine the association between governance controls and accruals estimation errors arising from manipulation of discretionary accruals and from environmental uncertainty. For this analysis we adopt the technique developed by Francis et al. (2005) which separates the DD measure of accruals quality into its 'discretionary’ and 'innate' components. The 'discretionary' component of accruals quality measures intentional manipulation of discretionary accruals. The 'innate' component measures unintentional estimation errors arising from the company's operating environment and related environmental uncertainty. To our knowledge, no prior study has directly examined the association between governance controls and innate accruals quality. In this respect, the current study represents an important contribution to existing research.

A further contribution arises from use of Australian company data for our analysis. Prior research demonstrates the lack of accuracy in estimating operating cash flow and components of operating cash flow when using mechanical rules (Austin and Bradbury, 1995). The DD approach to determining accruals quality is problematic in this regard as it substitutes cash from operations (CFO) for the actual operating cash flows related to working capital accruals. CFO is therefore a potentially noisy measure of actual cash flows. Use of the CFO proxy is a consequence of data availability under the 'indirect' operating cash flow reporting regime which does not require reporting of disaggregated CFO. Until 2009, Australian Accounting 
Standard AASB 127 'Statement of Cash Flows' mandated the 'direct' method for presentation of operating cash flows. Therefore, we are able to use selected components of operating cash flows that relate to working capital accruals. This permits an assessment of the extent of the noise resulting from using CFO in the DD model.

The extant earnings management literature is drawn upon to identify relevant governance mechanisms for our analysis. Prior studies suggest that the board of directors, the audit committee, and the external audit function are associated with the reliability of reported earnings (Davidson et al., 2005). The literature also identifies observable characteristics of these mechanisms that reflect sound governance and provide controls that improve the reliability of accounting information. The key characteristics for the board of directors are the inclusion of independent directors and the separation of the roles of chief executive officer (CEO) and board chair (Koh et al., 2007). Important characteristics for the audit committee are size, independence, expertise and diligence (DeZoort et al., 2002; Krishnan, 2005; Klein, 2002). An indication of sound governance for the external audit function is the engagement of a top tier audit firm (Cohen et al., 2002).

The results of our analysis show that sound governance is generally associated with both higher discretionary and innate accruals quality. We find a stronger and more robust association between sound governance and innate accruals quality than for discretionary accruals quality. Moreover, we find that the significance of variables differs across our regressions of governance mechanisms on the components of accruals quality. We find no significant association between board composition and discretionary accruals quality in our main analysis. In contrast, higher innate accruals quality is associated with a more independent board. Both discretionary and innate accruals quality are positively associated 
with the engagement of a Big 4 audit firm and with the existence of an audit committee that has characteristics that are representative of sound governance.

The paper proceeds as follows. In the next section, we review the related literature and develop hypotheses that are tested by our empirical analysis. The third section explains our research design, including sample selection and measurement of variables. The fourth section reports and discusses the results of the study's main analysis. This is followed by additional tests in section five. In the final section some conclusions are drawn, opportunities for further research are noted, and the limitations of the study are acknowledged.

\section{Literature review and hypotheses development}

\subsection{Accruals quality}

The DD model for determining accruals quality is based on the observation that the recording of accruals serves to shift or adjust the recognition of cash flows over time. DD show that earnings quality can be directly estimated by a regression of the change in working capital on past, current and future cash flows. DD use working capital accruals because they are generally realised within one year. The regression residual provides the measure of accruals quality as it measures the portion of accruals that does not closely estimate actual cash flows. A larger residual signifies greater overall accruals estimation error and therefore lower accruals quality. DD suggest that the standard deviation of the residual is the appropriate measure of accruals quality for a series of accruals quality measures taken over time. Several recent studies have adopted the DD model to measure the quality of earnings information (Francis et al., 2005; Biddle and Hilary, 2006; Ashbaugh-Skaife et al., 2006; Chen et al., 2007; Doyle et al., 2007; Srinidhi and Gul, 2007). 
Estimation of accruals is an inherently subjective process, which means that accruals are a noisy measure of the benefits or obligations they represent. Uncertainty about the amount of cash to be realised from accruals increases the range of accruals values that might be recorded. The result is an increased likelihood of accruals estimation error (Richardson et al. 2005). The extent of this estimation error has been associated with intentional earnings management in the form of accruals manipulation, and unintentional errors resulting from uncertainty associated with the company’s innate operating environment.

A substantive body of research exists that has examined the relation between earnings management and accruals quality. Prior studies have shown the opportunistic management of company earnings by the systematic manipulation of discretionary accruals is negatively associated with the quality of reported earnings (Davidson et al., 2005; Koh et al., 2007). However, the relation between environmental uncertainty and the quality of accruals estimation has been the focus of only a few studies. Examples include DD and Francis et al. (2005), both of whom report a positive relation between innate company characteristics that indicate a propensity for accruals estimation errors and the observed error.

\subsection{Accruals quality and corporate governance}

A key aim of corporate governance is to provide controls that ensure compliance with reporting requirements so that financial statements present fairly the financial affairs of the company (Davidson et al., 2005; Dechow et al., 1995). Prior research suggests that the monitoring associated with sound governance restricts opportunities for the manipulation of discretionary accruals, thereby having a positive association with the quality of reported earnings (Klein, 2002; Davidson et al., 2005; Koh et al., 2007). 
Corporate governance mechanisms are also likely to mitigate unintentional accruals estimation errors. Sound governance should ensure that necessary controls and sufficient expertise are at hand to ensure that accruals estimates are reliably determined. For example, sound governance should increase the probability that adequately trained and qualified personnel are involved in decision-making related to the provision of accounting information to management, or to ensure that sufficient controls are in place to detect reporting misstatements.

Prior empirical studies provide evidence of the importance of internal controls to mitigating the effects of environmental uncertainty on the quality of accruals estimation. Doyle et al. (2007) report that fundamental problems with a company’s internal control environment has a negative impact on accruals quality. Moreover, Ashbaugh-Skaife et al. (2007) show that remediation of a disclosed material control weakness is associated with an improvement in accruals quality. Importantly, Ashbaugh-Skaife et al. (2007) observe that internal control weaknesses are more likely to lead to unintentional accruals estimation errors than intentional accrual misstatements.

We posit, therefore, that the extent of accruals estimation errors varies according to the efficacy of corporate governance mechanisms in reducing the detrimental effects of earnings management and environmental uncertainty. In the following section, we develop hypotheses regarding the association between company characteristics that indicate sound governance and the quality of discretionary and innate components of accruals.

\subsection{Hypotheses development}

Corporate boards comprise both executive (inside) directors and independent (outside) 
directors. $^{2}$ Inside and outside directors play different roles and have different types of expertise (Kiel and Nicholson, 2003; Nicholson and Kiel, 2007). Inside directors have more specific knowledge about the company through their role as internal managers, while outside directors are more able to exercise independent judgment (Fama and Jensen, 1983). Understanding the governance role of inside and outside directors is assisted by reference to agency and stewardship theories.

We suggest that agency theory arguments are relevant for discretionary accruals quality. According to agency theory, boards should have a majority of outside directors in order to provide adequate monitoring to protect shareholders from the opportunistic behaviour of managers, including accruals manipulation (Kiel and Nicholson, 2003). Consistent with the agency view, corporate governance guidelines generally recommend that a majority of directors should be independent (Cadbury Report, 1992; Australian Securities Exchange (ASX), 2007). These directors are expected to act as arbiters in disagreements between internal managers, and to exercise independent judgement when conflicts of interest arise between managers and shareholders (Fama and Jensen, 1983). A key role of independent directors is to enhance the transparency and integrity of financial reporting (NYSE and NASD, 1999). They should therefore reduce the likelihood of earnings management resulting from the manipulation of discretionary accruals. Consistent with this proposition, Davidson et al. (2005) and Koh et al. (2007) report a significant negative relationship between board independence and earnings management in an Australian setting. Therefore, to the extent that outside directors have the knowledge, time and resources to effectively monitor management, we expect to observe a positive relation between board independence and discretionary accruals quality. Accordingly, we test the following hypothesis:

\footnotetext{
${ }^{2}$ A third category, known as 'grey' directors are those non-executive directors that have close affiliations with management (Raghunandan et al., 2001). For the purposes of this study, we include those directors as 'inside' directors.
} 
H1: Higher discretionary accruals quality is associated with a higher proportion of independent directors on the board.

We suggest that stewardship theory arguments are more relevant to innate accruals quality. Stewardship theory posits that managers are trustworthy and effective stewards of company resources (Donaldson, 1990; Donaldson and Davis, 1991, 1994; Nicholson and Kiel, 2007). From the stewardship perspective, the board's effective operation is reliant on an understanding of the company's business and quality of decision making rather than independent monitoring.

Where innate company characteristics make accruals estimation problematic, adequate stewardship is of greater importance than monitoring. Inside directors' superior knowledge of the company's business becomes increasingly important. Inside directors have access to specific information about the company and are expected to have greater knowledge than independent directors with respect to their company's innate characteristics (Fama and Jensen, 1983). According to stewardship theory, this superior knowledge leads to better decision making (Donaldson and Davis, 1991). It can be argued that this enhanced decision making ability extends to the more accurate estimation of accruals and their related future cash flows. This suggests that companies with more inside managers on the board are expected to have higher innate accruals quality. This leads to our second hypothesis:

H2: Higher innate accruals quality is associated with a lower proportion of independent directors on the board.

Substantial prior research indicates the critical role that the audit committee plays in relation to the quality of financial reporting. The board of directors delegates financial reporting 
responsibilities to the audit committee and this committee is the monitoring mechanism most likely to provide shareholders with the greatest protection by maintaining the quality of a company’s financial statements (Davidson et al., 2005; Kent and Stewart, 2008; Rainsbury et al., 2008). We expect that audit committees are committed to maintaining both discretionary and innate accruals quality. This is because they have an oversight function for high quality financial reporting, risk management and internal and external functions (Wolnizer, 1995, Rainsbury et al., 2008).

Independence of the audit committee is one of the key characteristics for effective audit committee operation (Jiambalvo, 1996; McMullen and Raghunandan, 1996; Krishnan, 2005; Koh et al., 2007). Davidson et al. (2005) and Koh et al. (2007) demonstrate that audit committee independence tends to moderate discretionary reporting behaviour for Australian companies.

Other characteristics of the audit committee shown to have assisted in ensuring high quality discretionary and innate accruals are expertise (DeZoort and Salterio, 2001; Knapp, 1987; Cohen et al., 2002), diligence in discharging responsibilities (Farber, 2005; Collier, 1993; Hughes, 1999; McMullen and Raghunandan, 1996), and the number of members (size), which enhances the committee's authority (Kalbers and Fogarty, 1993; Karamanou and Vafeas, 2005). In relation to the audit committee, the following hypothesis is tested.

H3: Higher discretionary and innate accruals quality are positively associated with independence, expertise, activity and size of the audit committee.

Prior international studies suggest that larger audit firms provide better quality audit services and a higher level of monitoring (DeAngelo, 1981; Francis et al., 1999; Kim et al., 2003). 
The audit firm size measure is generally based on whether a firm is one of the recognised top tier audit firms (now the 'Big 4'). Top tier audit firms have a greater ability to constrain ‘aggressive, potentially opportunistic reporting of accruals’ (Francis et al., 1999, p.18). Thus, we expect the use of a Big 4 audit firm to be associated with higher discretionary accruals quality. Earlier studies demonstrate that companies using 'Big 5' or 'Big 6' auditors report lower levels of earnings management than clients of smaller audit firms (Becker et al., 1998; Francis et al., 1999).

Big 4 auditors are also expected to have higher financial accounting expertise and greater knowledge of accounting principles than other firms. This additional accounting expertise is expected to assist Big 4 auditors to more accurately estimate future cash flows, enabling them to identify potential misstatements arising from estimations associated with environmental uncertainty.

While support has not been found for the relation of external auditor size to earnings management in prior Australian studies (Davidson et al., 2005; Koh et al., 2007), these studies have not distinguished between discretionary and innate accruals in the same way as in our study. Given the above discussion, we test the following hypothesis:

H4: Higher innate and discretionary accruals quality are positively associated with the engagement of a Big 4 audit firm.

\section{Research design}

The research design involves the development of ordinary least squares regression models to test the extent to which governance variables explain the variance in both innate and discretionary accruals quality for a sample of listed Australian public companies. 


\subsection{Sample selection}

The sample consists of listed Australian companies in 2004 with a 30 June balance date. A preliminary sample of 900 companies was identified from the Aspect DatAnalysis database. Financial data were collected for the years 2000 to 2006 from the Aspect FinAnalysis database, so that the accruals quality measures could be calculated for 2001 to $2005^{3}$. Data for the governance variables were hand collected from published annual reports for the financial year ending 2004. Applying the requirement that sample companies have an audit committee and that data were available for the required years resulted in a sample of 392 companies in the governance regressions. For regressions used to calculate measures of accrual quality, we included companies that did not have an audit committee. This means the determination of accruals quality was based on a larger sample of companies (see relevant tables for sample size) thereby providing a more robust measure.

\subsection{Determining accruals quality}

The benefit of reporting accruals-based earnings is that they better represent underlying economic performance than cash flows. Accruals require estimates to be made and are subject to discretion. Therefore, as DD observe, the benefit of using accruals comes at the cost of estimation errors being included in reported earnings. DD develop the following model of working capital accruals to empirically determine accruals quality:

$$
\Delta W C_{t}=\beta_{0}+\beta_{1} * C F O_{t-1}+\beta_{2} * C F O_{t}+\beta_{3} * C F O_{t+1}+\varepsilon_{t}
$$

Where:

$\Delta W C_{t}=$ Comprehensive measure of change in working capital accruals, including change in: accounts receivable, accounts payable, current inventory, current investments, current

\footnotetext{
${ }^{3}$ A lead and lag year is required for the DD model calculation.
} 
provisions, and other current assets and liabilities.

$C F O_{t-1}=$ Cash flow from operations in $t-1$.

$C F O_{t}=$ Cash flow from operations in $t$.

$C F O_{t+1}=$ Cash flow from operations in $t+1$.

$\varepsilon_{t}=$ residual

Variables are scaled by average total assets.

The regression residual provides a measure of accruals quality; it represents the portion of accruals that is not estimated by actual cash flows. DD suggest that, for a series of measures of accruals quality over time, the standard deviation of the residuals is the appropriate measure of overall accruals quality. A higher (lower) standard deviation signifies higher (lower) accruals estimation error and therefore lower (higher) accruals quality.

McNichols (2002) tested a variation to the DD model that includes a measure of change in sales (see Equation 2 below) and the size of property, plant and equipment. Both McNichols (2002) and Francis et al. (2005) show an improvement in model fit by augmenting the original DD model with these variables taken from the Jones (1991) model. According to McNichols (2002), these variables are important to forming expectations about current accruals above the contribution of operating cash flows.

We use both the DD model (see Equation 1 above) and the McNichols (2002) variation to estimate accruals quality. We introduce a minor variation to the McNichols model by using the change in operating revenue $(\triangle R E V)$ rather than sales (see Equation 2 below). This variation enables us to retain companies in our sample that do not report sales.

$\Delta W C_{t}=\beta_{0}+\beta_{1} * C F O_{t-1}+\beta_{2} * C F O_{t}+\beta_{3} * C F O_{t+1}+\beta_{4} * \Delta R E V_{t}+\beta_{5} * P P E_{t}+\varepsilon_{t}$ 
Where:

$\Delta W C_{t}=$ Comprehensive measure of change in working capital accruals including change in: accounts receivable, accounts payable, current inventory, current investments, current provisions, and other current assets and liabilities.

$C F O_{t-1}=$ cash flow from operations in $t-1$.

$C F O_{t}=$ cash flow from operations in $t$.

$C F O_{t+1}=$ cash flow from operations in $t+1$.

$\Delta R E V_{t}=$ change in operating revenue from $t-1$ to $t$.

$P P E_{t}=$ Property Plant and Equipment reported at $t$.

$\varepsilon_{t}=$ residual

All variables are scaled by average total assets.

Regressions are conducted for each of five years from 2001 to 2005, thereby providing five measures of accruals quality for each company. The overall accruals quality measure is then determined by taking the standard deviation of the regression residuals for each company over the five years.

\subsection{Determining the innate and discretionary components of accruals quality}

Separating accruals quality into innate and discretionary accruals involves estimating a regression of the DD accruals quality measure on 'innate' company characteristics (Francis et al., 2005). The selected innate characteristics follow DD and Francis (2005), and include measures of company size, incidence of negative earnings, length of operating cycle, and volatility of operating environment. ${ }^{4}$ To determine the components of accruals quality, the

\footnotetext{
${ }^{4}$ Francis et al. (2005) also include the standard deviation of operating cash flow as a proxy for volatility of operating environment. We use only the standard deviation of operating revenue as our proxy of this to avoid multicollinearity problems. We performed our analyses using the standard deviation of operating cash flow and results were qualitatively similar.
} 
regression shown in Equation 3 below was calculated.

$$
A Q=\alpha+\beta_{1} * S I Z E+\beta_{2} * \text { LOSS }+\beta_{3} * O P C Y C+\beta_{4} * S D O R+\varepsilon_{t}
$$

Where:

$A Q=$ Accruals quality (standard deviation of the regression residuals for 2001 to 2005).

SIZE = Natural log of total assets for 2004

LOSS = Number of years in which a loss was recorded for 2002 to 2004.

OPCYC = Natural log of average age of inventory plus the average age of receivables (in days) 2003 and 2004 after winsorising at 365 days. $^{5}$

SDOR = Standard deviation of operating revenue divided by total assets for 2001 to 2005 .

The regression predicted values are the estimate of innate accruals quality (IAQ), and the residual values are the estimate of discretionary accruals quality (DAQ). Innate and discretionary accruals quality are determined for AQ measures derived from the DD model and the McNichols (2002) variation.

\subsection{Measurement of governance variables}

We measure board independence using two variables: the proportion of independent (inside) directors and a dummy variable indicating whether the roles of the chairperson and CEO are separate. Most companies specify whether directors are independent or non-executive, however, where no mention of independence is made we assume that the director is not independent. It is generally recognised that there is a lack of board independence when one person holds the positions of chairperson and CEO. As such, the ASX Corporate Governance Guidelines (ASX, 2007) specifically recommend that these roles should not be held by the

\footnotetext{
${ }^{5}$ Approximately 8 per cent of cases were winsorised in order to remove the possibility of bias due to extreme values.
} 
same person. We use the existence of dual chairperson and CEO as an indicator of weakness of independence and related board monitoring, but as an indicator of strength in regard to knowledge of company operations.

Audit committee independence is measured as the proportion of committee members that are described as independent directors. The proportion of committee members with formal qualifications in accounting and finance (for example, CA or CPA) is included as a proxy for expertise. The number of audit committee meetings held during the year measures diligence, and audit committee size is measured as the number of directors assigned to the audit committee.

In addition to the individual audit committee variables, a composite variable is calculated to measure audit committee quality. This approach has been used in prior studies to overcome a concern that the audit committee variables are highly correlated and hence potentially unstable. Consistent with prior studies, we determine a dummy variable that identifies companies with audit committees that approximate best practice (Rainsbury et al., 2008). We identify companies that meet the following criteria: the audit committee (1) is wholly comprised of independent and non-executive directors; (2) has three or more directors assigned to the committee; (3) meets at least as frequently as the sample mean (three meetings per year); and, (4) has at least one committee member with professional accounting qualifications (ASX, 2007; Blue Ribbon Committee, 1999). The dummy variable for audit committee best practice (ACBP) is coded one (1) for companies meeting all of these criteria and zero (0) otherwise.

Our audit firm variable is a dummy variable identifying companies that have utilised the 
audit services of one of the Big 4 firms as one (1) and zero (0) otherwise.

\subsection{Governance regression models}

Our hypotheses regarding corporate governance mechanisms are tested by regressions of the selected governance variables on innate accruals quality (IAQ) and discretionary accruals quality (DAQ) determined according to Equation (3) above. The regression models calculated are shown below:

$$
\begin{aligned}
& D A Q=\beta_{0}+\beta_{1} * \text { PROIND }+\beta_{2} * D U A L+\beta_{3} * A U D I T O R+\beta_{4} * N D I R A C+ \\
& \beta_{5} * P R O I N D A C+\beta_{6} * M E E T A C+\beta_{7} * P R O E X P+\varepsilon_{t} \\
& D A Q=\beta_{0}+\beta_{1} * P R O I N D+\beta_{2} * D U A L+\beta_{3} * A C B P+\beta_{4} * A U D I T O R+\varepsilon_{t} \\
& I A Q=\beta_{0}+\beta_{1} * P R O I N D+\beta_{2} * D U A L+\beta_{3} * A U D I T O R+\beta_{4} * N D I R A C+ \\
& \beta_{5} * P R O I N D A C+\beta_{6} * M E E T A C+\beta_{7} * P R O E X P+\varepsilon_{t} \\
& I A Q=\beta_{0}+\beta_{1} * P R O I N D+\beta_{2} * D U A L+\beta_{3} * A C B P+\beta_{4} * \text { AUDITOR }+\varepsilon_{t}
\end{aligned}
$$

Where:

$D A Q=$ Discretionary accruals quality.

$I A Q=$ Innate accruals quality.

PROIND $=$ Number of independent directors divided by the number of directors.

DUAL = Dummy, coded 1 if CEO is chair of board of directors, coded 0 otherwise.

AUDITOR = Dummy, coded 1 if appointed auditor is one of the Big 4 firms.

NDIRAC $=$ Number of directors on the audit committee.

PROINDAC $=$ Proportion of independent directors on the audit committee .

MEETAC = Number of audit committee meetings each year.

PROEXP = Number of audit committee members with professional accounting qualifications divided by the number of committee members. 
ACBP = Dummy, coded 1 for committees that are wholly comprised of independent and nonexecutive directors; have three or more directors assigned; meet at least as frequently as the sample mean; and, have one committee member with professional accounting qualifications. Coded 0 otherwise.

\section{Results}

\subsection{Descriptive statistics}

Table 1 provides descriptive statistics for the sample characteristics and variables included in the models. Statistics for the sample companies' innate characteristics show the mean total asset size was $\$ 734$ million. The average age of inventory plus the average age of receivables was 106 days, and the mean standard deviation of operating revenue (SDOR) was 0.310. The average of the number of years in which a negative net profit after tax was reported (LOSS) was 1.195.

The descriptive statistics for board characteristics vary across the sample companies. The average proportion of independent directors (PROIND) is 53 percent, and only 11 percent of companies in the sample have a joint CEO and board chair (DUAL). Audit committee size (NDIRAC) ranges from one to seven with a median of three. On average, 24 percent of audit committee members have accounting and finance expertise (PROEXP). The frequency of audit committee meetings (MEETAC) ranges from zero to 16 per year, with a median of three per year. Audit committee independence (PROINDAC) is favourable, with 88 percent of members being independent directors. For our audit committee composite variable (ACBP), only 19 percent of companies met the criteria for best practice characteristics. In relation to external audit (AUDITOR), 61 percent of the sample companies utilise the services of one of the Big 4 audit firms. 
Table 2 reports correlation measures for all independent variables included in the regression analyses. Correlations between variables were not of a sufficient magnitude to raise concerns about multicollinearity for the regression analyses (Tabachnick and Fidell 1996). Variance inflation factor statistics were also examined and did not indicate problems with multicollinearity. Therefore, we present analysis using separate governance measures rather than a composite governance measure as has been used in prior studies (Beekes and Brown, 2006). Our approach enables assessment of individual governance measures on accruals quality. However, to assess the robustness of our results, we also report analysis using our composite measure of audit committee quality.

\subsection{Accruals quality regressions}

Accruals quality is determined for the years 2001 to 2005 using Equations 1 and 2. Table 3 reports the results. The standard deviation of the five years of calculated regression residuals is the overall measure of accruals quality (AQ) for each company. We find that overall the DD and the augmented McNichols (2002) models performed similarly, although the McNichols model provided a significantly higher $\mathrm{R}^{2}$ in 2005.

Each company's accruals quality measure is regressed against innate company characteristics to determine the discretionary and innate components of accruals quality (see Equation 3 above). Results of this regression using the accruals quality measure determined from both the DD model and the McNichols (2002) model are presented in Table 4. The results are consistent for both models of accruals quality. Company size, loss years and volatility in operating revenue are significant for innate characteristics. Larger companies have higher accruals quality (lower standard deviation of residuals); and those with more volatile 
operating revenues and loss years have lower accruals quality (higher standard deviation of residuals). These results are consistent with the earlier findings of $\mathrm{DD}$ and Francis et al. (2005).

\subsection{Governance regressions and discretionary accruals quality}

The regressions of governance characteristics on the measure of DAQ derived from the McNichols (2002) model are reported in Panel A of Table 5, with Model 1 using separate audit committee quality measures and Model 2 using the composite measure of a best practice audit committee. The models show that only a relatively small proportion of the variance in DAQ is explained by the selected governance variables $\left(R^{2}=0.028\right.$ for Model 1 and $\mathrm{R}^{2}=0.012$ for Model 2).

The two board independence variables are not significant in either model and, therefore, the results provide no support for $\mathrm{H} 1$. In relation to the separate audit committee measures in Model 1, a greater number of members (NDIRAC) is significant $(p<0.05)$. The proportion of independent directors on the committee (PROINDAC) and the number of committee meetings (MEETAC) are significant $(p \leq 0.10)$, with a greater proportion of independent directors on the audit committee and more audit committee meetings associated with higher DAQ. However, the audit committee expertise variable (PROEXP) is not significant. Further, the audit committee composite variable in Model 2 is also not significant. Thus, overall, there is only weak support for H3 with respect to DAQ. The engagement of a Big 4 audit firm (AUDITOR) is significant in both models $(p<0.05)$ and is associated with higher DAQ, providing support for $\mathrm{H} 4$.

The analysis using the accruals quality measure derived from the DD model is presented in 
Panel B of Table 5. Overall, the results are qualitatively similar to those reported above for the McNichols (2002) model, with the difference being a non-significant result for the number of audit committee meetings in Model 1.

The non-significant result for the board independence variables is inconsistent with prior Australian studies, which have reported a negative relationship between earnings management and board independence (Davidson et al., 2005; Koh et al., 2007). These studies also failed to find an association between higher DAQ and the use of a Big 4 audit firm, which is again inconsistent with our results. We suggest the conflicting results may be a consequence of the different methods used to determine accruals quality. The finding indicates a need for further testing of the efficacy of the available methods for determining accruals and earnings quality.

\subsection{Governance regressions and innate accruals quality}

The regressions of governance characteristics on IAQ derived from the McNichols (2002) model are reported in Panel A of Table 6, with Model 3 using separate audit committee quality measures and Model 4 using the audit committee composite measure. The strength of association between the governance variables and IAQ is much greater than that observed for DAQ as reported above $\left(\mathrm{R}^{2}=0.319\right.$ for Model 3 and $\mathrm{R}^{2}=0.214$ for Model 4$)$. We find for IAQ that characteristics of the board, audit committee, and the external auditor are significant.

In relation to board characteristics, existence of a CEO that is also the board chair (DUAL) is significant in both models ( $p=0.046$ in Model 3, and $p=0.019$ in Model 4) and is associated with lower IAQ. In Model 4, the proportion of independent directors on the board (PROIND) is also significant $(p<0.10)$, with a greater proportion of independent directors associated 
with higher IAQ. Therefore, contrary to the expectations outlined in H2, we find that board independence is important to maintaining the accuracy of innate accruals estimation. This finding suggests that inside directors' superior knowledge of the company's business does not translate into higher innate accruals quality. Rather, it suggests that stronger internal controls required by outside directors lead to a lower level of unintentional accruals estimation errors (Ashbaugh-Skaife et al., 2007).

Of the audit committee variables, Model 3 shows that committee size (NDIRAC) and number of meetings (MEETAC) are significant $(p<0.001)$, while the proportion of independent directors assigned to the committee (PROINDAC) is significant $(p=0.017)$. Consistent with expectations, larger audit committees, a greater proportion of independent directors and more frequent committee meetings are associated with higher innate accruals quality. Model 4 provides further support that a best practice audit committee is associated with higher innate accruals quality $(\mathrm{p}<0.001)$. Thus, with the exception of audit committee expertise (PROEXP), which is not significant, these results confirm the expectations outlined in H3. Consistent with the expectations of $\mathrm{H} 4$, engagement of a Big 4 audit firm is significant $(p<0.001)$ and associated with higher innate accruals quality in Model 3 and Model 4.

The same analysis using the accruals quality measure derived from the DD model is presented in Panel B of Table 6. The results are generally consistent with those reported above for the McNichols (2002) model.

In summary, our initial analysis of the association between governance characteristics and DAQ and IAQ suggests the following. First, the use of a top tier audit firm is associated with both higher DAQ and IAQ. Second, there is no evidence to support an association between 
an independent board and higher DAQ. There is support for an association between a larger audit committee and higher DAQ and weaker support for a more independent, more active audit committee and higher DAQ. An independent board and a larger, more independent and more diligent audit committee are both associated with higher IAQ. Finally, a greater proportion of audit committee members with accounting expertise are not associated with higher DAQ or higher IAQ. ${ }^{6}$

\section{Additional analyses}

Additional analyses were conducted to test the sensitivity of the main results. The first of these involved replacing the variables for audit committee characteristics with a single indicator variable for the existence of an audit committee. The untabulated results indicate that the existence of an audit committee is significantly associated with higher accruals quality for both discretionary and innate accruals ( $\mathrm{p}=0.001$ and $\mathrm{p}<0.001$ respectively). The engagement of a Big 4 auditor is also significantly associated with DAQ and IAQ ( $p=0.019$ and $\mathrm{p}<0.001$ respectively).

Second, analysis was conducted to consider the impact of noise associated with using net cash from operations (CFO) as a proxy for cash flows that relate to changes in working capital. The use of CFO as a proxy for cash flows that relate to changes in working capital is a source of model misspecification. As DD note, the regression of CFO on working capital accruals is problematic because only portions of past, present and future operating cash flows are related to working capital accruals. Hence, CFO is potentially a noisy measure of the independent variables in the regression. McNichols (2002, p.67) provides empirical evidence of this noise. The use of CFO in the development of the DD model is a consequence of data

\footnotetext{
${ }^{6}$ This result could indicate that the proportion of audit committee members with a professional accounting qualification is a poor proxy for the expertise of the audit committee.
} 
availability under the indirect operating cash flow reporting regime. The indirect method does not require reporting of disaggregated operating cash flows, thereby requiring large sample analysis to use the CFO proxy. To test for possible misspecification on our initial findings, we calculate additional accruals quality regressions using targeted components of operating cash flows.

The components included are 'cash receipts from customers' (CRC) and 'cash payments to suppliers and employees' (CPSE). This adjustment is possible as the requisite data are available for Australian companies up to the beginning of 2009 because they have been required by AASB 127 'Statement of Cash Flows' to apply the direct method for operating cash flows presentation. A further adjustment to the model is the use of working capital (WC) accounts in our accruals calculation that are most likely to estimate the selected cash flows. These are accounts receivable and accounts payable. The model is shown in equation (8) below:

$$
\begin{aligned}
& \Delta W C=\beta_{0}+\beta_{1} *[C R C+C P S E]_{t-1}+\beta_{2} *[C R C+C P S E]_{t}+\beta_{3} *[C R C+C P S E]_{t+1}+ \\
& \beta_{4} * \Delta R E V_{t}+\beta_{5} * P P E_{t}+\varepsilon_{t}
\end{aligned}
$$

Where:

$\Delta W C=$ Change in accounts receivable minus change in accounts payable

$[C R C+C P S E]_{t-1}=$ Net cash receipts from customers and cash payments to suppliers in $t-1$.

$[C R C+C P S E]_{t}=$ Net cash receipts from customers and cash payments to suppliers in $t$.

$[C R C+C P S E]_{t+1}=$ Net cash receipts from customers and cash payments to suppliers in $t+1$.

$\Delta R E V_{t}=$ change in operating revenue from $t-1$ to $t$.

$P P E_{t}=$ Property, Plant and Equipment reported at $t$.

$\varepsilon_{t}=$ Residual.

All variables are scaled by average total assets. 
Results of governance regressions of accruals quality using the McNichols model and separate audit committee characteristics are reported in Table $7 .{ }^{7}$ For DAQ, audit committee size (NDIRAC) and the number of committee meetings (MEETAC) are significant (at $p<0.10$ ), with a greater number of directors on the audit committee and more audit committee meetings associated with higher DAQ. Interestingly, the proportion of independent directors (PROIND) is also significant $(p<0.05)$, with a greater proportion of independent directors associated with higher DAQ. This latter finding provides some support for H1 and is consistent with the results of prior Australian studies which have used the modified Jones (1991) model to measure discretionary accruals (Davidson et al., 2005; Koh et al., 2007). Again, this suggests that results are sensitive to different models for determining accruals quality, indicating the need for further testing and refining of these models. For IAQ, the results are consistent to those reported in the initial analysis.

\section{Summary and conclusions}

The empirical analysis presented in this paper provides further useful insight into the important issue of how corporate governance mechanisms relate to the quality of reported company earnings. We apply the McNichols (2002) and the DD models to measure overall accruals quality, and then use the technique developed by Francis et al. (2005) to separate the accruals quality measure into components attributable to earnings management (discretionary accruals quality) and environmental uncertainty (innate accruals quality). These components of accruals quality are used as the dependent variables in regressions on corporate governance mechanisms.

For discretionary accruals quality we find the engagement of a Big 4 external audit firm and

\footnotetext{
${ }^{7}$ Untabulated regression results for this measure of accruals quality using the composite variable for best practice audit committees are qualitatively similar to those reported in our main analysis.
} 
the size of the audit committee are the primary governance mechanisms that are associated with higher discretionary accruals quality. There is also some evidence to suggest that other audit committee characteristics such as meeting frequency and independence are positively associated with discretionary accruals quality.

Our results for discretionary accrual quality are in contrast to those of prior Australian studies that have examined the association between corporate governance and earnings management Davidson et al., 2005; Koh et al., 2007). The inconsistency of the results for discretionary accrual quality may be a result of model specification issues. McNichols (2000) documents the specification problems that arise from using aggregated accruals data and the consequential difficulty with empirically determining the effects of accounting discretion on earnings or accruals quality.

For innate accruals quality we find higher quality is associated with an independent board of directors, a larger, more independent and more active audit committee, and the engagement of a Big 4 external audit firm. Our results suggest that lack of board independence and associated weakness in overall governance related controls leads to lower innate accruals estimation accuracy. Inside directors' superior knowledge of environmental uncertainty is not reflected in more accurate accruals estimation. Moreover, the controls provided by the audit committee and the external audit function serve to improve the estimation of accruals despite environmental uncertainty.

Our analysis has important implication for regulators. Our study demonstrates that corporate governance characteristics have weak power in explaining discretionary accruals and that discretionary accruals are difficult to measure. Our innate accruals model has increased 
explanatory power and the proportion of independent directors and companies with best practice audit committees significantly contribute to that explanatory power. Regulators may therefore need to consider expanding the requirement for best practice audit committees to all listed companies. ${ }^{8}$ Regulators also need to focus on the optimal mix of outside and inside directors for achieving higher quality financial reporting.

The findings suggest that ongoing research opportunities exist in comparative testing of methods of estimating accruals quality. For example, McNichols (2000, 2002) suggests that model specification problems can be minimised by examining individual accrual accounts rather than aggregate data. Gaining further insight into why governance mechanisms have a different impact on one source of accruals estimation error than another is an interesting avenue for future research.

There are several limitations to this study. First, our measure of accruals quality is limited to considering current accruals and their related cash flows. This approach does not provide a comprehensive analysis of accruals quality as it excludes components of reported earnings not associated with current accruals. Second, in relation to sampling, there is a self-selection concern arising from the requirement that sample firms have an audit committee. This may bias the sample towards larger firms since the top 500 firms listed on the ASX in the sample period are required to have an audit committee. Third, the results of the analysis are subject to the effectiveness of the measures that operationalise various characteristics of corporate governance mechanisms. Data availability has prevented the inclusion of governance variables that may have a bearing on accruals quality. Finally, our study is based on the

\footnotetext{
${ }^{8}$ Currently, the ASX Listing Rules mandate the establishment of audit committees by companies comprising the S\&P All Ordinaries Index and require that the composition, operation and responsibility of the audit committee of companies in the top 300 of that Index comply with the ASX Corporate Governance Guidelines (ASX, 2007).
} 
assumption that governance mechanisms influence accruals behaviour. However, it is possible that a firm's level of accruals may explain the type of governance mechanisms in place. This would suggest the possibility of an endogeneity issue which could be explored in future research. 
Table 1

Descriptive statistics - independent variables $(n=392)$

\begin{tabular}{|c|c|c|c|c|c|}
\hline Variable & Mean & $\begin{array}{l}\text { Standard } \\
\text { Deviation }\end{array}$ & Minimum & Median & Maximum \\
\hline \multicolumn{6}{|c|}{ Panel A: Sample characteristics } \\
\hline Total assets (000’s) & 734180 & 3365783 & 57417 & 792711 & 45259316 \\
\hline $\begin{array}{l}\text { Average age of } \\
\text { inventory and } \\
\text { receivables (days) }\end{array}$ & 106 & 90 & 1 & 81 & 365 \\
\hline $\begin{array}{l}\text { Net profit after tax / } \\
\text { Average total assets }\end{array}$ & -0.042 & 0.322 & -2.062 & 0.045 & 1.225 \\
\hline \multicolumn{6}{|c|}{ Panel B: Continuous regression variables } \\
\hline SIZE & 18.141 & 1.972 & 13.583 & 17.866 & 24.536 \\
\hline OPCYC & 4.319 & 0.902 & 0.196 & 4.389 & 5.900 \\
\hline LOSS & 1.195 & 1.217 & 0 & 1 & 3 \\
\hline SDOR & 0.310 & 0.441 & 0 & 0.182 & 3.624 \\
\hline SDOCF & 0.114 & 0.140 & 0 & 0.067 & 1.680 \\
\hline PROIND & 0.526 & 0.215 & 0 & 0.500 & 1 \\
\hline NDIRAC & 2.910 & 0.830 & 1 & 3 & 7 \\
\hline PROINDAC & 0.877 & 0.226 & 0 & 1 & 1 \\
\hline MEETAC & 3.270 & 1.828 & 0 & 3 & 16 \\
\hline PROEXP & 0.242 & 0.274 & 0 & 0.25 & 1 \\
\hline \multicolumn{6}{|c|}{ Panel C: Dummy regression variables } \\
\hline & \multicolumn{2}{|c|}{ Coded 1} & \multicolumn{3}{|c|}{ Coded 0} \\
\hline DUAL & \multicolumn{2}{|c|}{$11 \%$} & \multicolumn{3}{|c|}{$89 \%$} \\
\hline AUDITOR & \multicolumn{2}{|r|}{$61 \%$} & \multicolumn{3}{|c|}{$39 \%$} \\
\hline ACBP & \multicolumn{2}{|r|}{$19 \%$} & \\
\hline
\end{tabular}

SIZE = Natural log of total assets at $t$.

OPCYC = Natural log of average age of inventory plus the average age of receivables (in days) 2003 and 2004 after winsorising at 365 days.

LOSS = Number of years in which a loss was recorded for 2002 to 2004.

SDOR = Standard deviation of operating revenue divided by average total assets for 2001 to 2005.

DSOCF = Standard deviation of operating cash flow divided by average total assets fro 2001 to 2005.

PROIND $=$ Number of independent directors divided by the number of directors.

NDIRAC $=$ Number of directors on the audit committee.

PROINDAC $=$ Proportion of independent directors on the audit committee.

MEETAC $=$ Number of audit committee meetings each year.

PROEXP = Number of audit committee members with professional accounting qualifications divided by the number of committee members.

$D U A L=$ Dummy, coded 1 if CEO is chair of board of directors, coded 0 otherwise.

AUDITOR = Dummy, coded 1 if appointed auditor is one of the Big 4 firms.

ACBP = Dummy, coded 1 for committees that are wholly comprised of independent and non-executive directors; have three or more directors assigned; meet at least as frequently as the sample mean; and, have one committee member with professional accounting qualifications. Coded 0 otherwise. 
Table 2

Correlation matrices - independent variables $(\mathrm{n}=392)$

\begin{tabular}{|c|c|c|c|c|}
\hline & SIZE & LOSS & OPCYC & SDOR \\
\hline SIZE & 1 & & & \\
\hline LOSS & $* *-0.614$ & 1 & & \\
\hline OPCYC & -0.006 & 0.002 & 1 & \\
\hline SDOR & $* *-0.204$ & $* * 0.102$ & $*_{-0} 0.084$ & 1 \\
\hline
\end{tabular}

Panel B: Governance variables

\begin{tabular}{|c|c|c|c|c|c|c|c|}
\hline & PROIND & DUAL & AUDITOR & NDIRAC & PROINDAC & MEETAC & PROEXP \\
\hline PROIND & 1 & & & & & & \\
\hline DUAL & -0.089 & 1 & & & & & \\
\hline AUDITOR & $* * 0.187$ & $*-0.106$ & 1 & & & & \\
\hline NDIRAC & *0.124 & *-0.120 & $* * 0.197$ & 1 & & & \\
\hline PROINDAC & $* * 0.314$ & $*_{-0.115}$ & $* * 0.225$ & -0.037 & 1 & & \\
\hline MEETAC & $* * 0.204$ & -0.043 & $* * 0.202$ & $* * 0.175$ & $* * 0.215$ & 1 & \\
\hline PROEXP & 0.002 & 0.027 & -0.030 & $* * 0.145$ & 0.047 & 0.086 & 1 \\
\hline ACBP & $* * 0.175$ & -0.091 & $* * 0.190$ & $* * 0.258$ & $* * 0.269$ & $* * 0.396$ & $* * 0.295$ \\
\hline
\end{tabular}

** Denotes significant at $p<0.01$; * denotes significant at $p<0.05$

SIZE = Natural log of total assets at $t$.

LOSS = Number of years in which a loss was recorded for 2002 to 2004.

$O P C Y C=$ Natural log of average age of inventory plus the average age of receivables (in days) 2003 and 2004 after winsorising at 365 days.

SDOR = Standard deviation of operating revenue divided by total assets for 2001 to 2005.

$P R O I N D=$ Number of independent directors divided by the number of directors.

DUAL = Dummy, coded 1 if CEO is chair of board of directors, coded 0 otherwise.

AUDITOR = Dummy, coded 1 if appointed auditor is one of the Big 4 firms.

NDIRAC = Number of directors on the audit committee.

PROINDAC = Proportion of independent directors on the audit committee.

MEETAC = Number of audit committee meetings each year.

PROEXP = Number of audit committee members with professional accounting qualifications divided by the number of committee members

ACBP = Dummy, coded 1 for committees that are wholly comprised of independent and non-executive directors; have three or more directors assigned;

meet at least as frequently as the sample mean; and, have one committee member with professional accounting qualifications. Coded 0 otherwise. 
Table 3

Regression results - accruals models

\begin{tabular}{|c|c|c|c|c|c|c|c|c|}
\hline & & Int. & $\mathrm{CFO}_{\mathrm{t}-1}$ & $\mathrm{CFO}_{\mathrm{t}}$ & $\mathrm{CFO}_{\mathrm{t}+1}$ & $\Delta \mathrm{REV}_{\mathrm{t}}$ & $\mathrm{PPE}_{\mathrm{t}}$ & Adj. $\mathrm{R}^{2}$ \\
\hline 2005 & & & & & & & & \\
\hline DD Model & Coefficient & 0.011 & 0.095 & -0.362 & 0.329 & & & 0.125 \\
\hline$(n=712)^{\mathrm{a}}$ & t-statistic & 1.732 & 2.721 & -8.398 & 8.698 & & & \\
\hline & $p$ value & 0.084 & 0.007 & 0.000 & 0.000 & & & \\
\hline McNichols & Coefficient & 0.007 & 0.136 & -0.300 & 0.299 & 0.044 & -0.011 & 0.201 \\
\hline Model & t-statistic & 0.769 & 3.892 & -7.025 & 8.031 & 3.075 & -0.749 & \\
\hline$(n=468)^{\mathrm{a}}$ & $p$ value & 0.442 & 0.000 & 0.000 & 0.000 & 0.002 & 0.454 & \\
\hline 2004 & & & & & & & & \\
\hline DD Model & Coefficient & 0.011 & 0.129 & -0.321 & 0.111 & & & 0.044 \\
\hline$(n=718)^{\mathrm{a}}$ & t-statistic & 1.161 & 2.663 & -5.542 & 1.852 & & & \\
\hline & $p$ value & 0.246 & 0.008 & 0.000 & 0.064 & & & \\
\hline McNichols & Coefficient & 0.016 & 0.020 & -0.155 & 0.015 & 0.006 & -0.002 & 0.030 \\
\hline Model & $t$-statistic & 1.324 & 0.446 & -3.188 & 0.320 & 0.514 & -0.096 & \\
\hline$(n=496)^{\mathrm{a}}$ & $p$ value & 0.186 & 0.656 & 0.002 & 0.749 & 0.924 & 0.608 & \\
\hline 2003 & & & & & & & & \\
\hline DD Model & Coefficient & 0.003 & 0.068 & -0.234 & 0.238 & & & 0.067 \\
\hline$(n=713)^{\mathrm{a}}$ & t-statistic & 0.457 & 1.388 & -5.522 & 6.155 & & & \\
\hline & $p$ value & 0.648 & 0.166 & 0.000 & 0.000 & & & \\
\hline McNichols & Coefficient & 0.001 & 0.153 & -0.253 & 0.189 & -0.026 & 0.001 & 0.086 \\
\hline Model $^{\mathrm{a}}$ & $t$-statistic & 0.052 & 3.356 & -5.545 & 4.786 & -1.756 & 0.049 & \\
\hline$(n=513)$ & $p$ value & 0.959 & 0.001 & 0.000 & 0.000 & 0.080 & 0.961 & \\
\hline 2002 & & & & & & & & \\
\hline DD Model & Coefficient & 0.004 & -0.070 & 0.223 & 0.065 & & & 0.041 \\
\hline$(n=652)^{\mathrm{a}}$ & t-statistic & 0.431 & -1.222 & 3.326 & 1.227 & & & \\
\hline & $p$ value & 0.666 & 0.222 & 0.001 & 0.220 & & & \\
\hline McNichols & Coefficient & 0.043 & -0.007 & 0.176 & 0.109 & 0.019 & -0.089 & 0.043 \\
\hline Model & $t$-statistic & 2.462 & -0.104 & 2.289 & 1.681 & 0.985 & -2.671 & \\
\hline$(n=484)^{\mathrm{a}}$ & $p$ value & 0.014 & 0.917 & 0.023 & 0.093 & 0.325 & 0.008 & \\
\hline 2001 & & & & & & & & \\
\hline DD Model & Coefficient & 0.002 & 0.151 & -0.251 & 0.273 & & & 0.078 \\
\hline$(n=649)^{\mathrm{a}}$ & t-statistic & 0.260 & 3.170 & -5.026 & 6.205 & & & \\
\hline & $p$ value & 0.795 & 0.002 & 0.000 & 0.000 & & & \\
\hline McNichols & Coefficient & 0.029 & 0.092 & -0.198 & 0.277 & -0.004 & -0.057 & 0.061 \\
\hline Model & $t$-statistic & 2.243 & 1.723 & -3.448 & 5.393 & -0.250 & -2.269 & \\
\hline$(n=479)^{\mathrm{a}}$ & $p$ value & 0.025 & 0.086 & 0.001 & 0.000 & 0.803 & 0.024 & \\
\hline
\end{tabular}

$\Delta W C_{t}=$ Comprehensive measure of change in working capital accruals including change in: accounts receivable, accounts payable, current inventory, current investments, current provisions, and other current assets and liabilities.

$C F O_{t-1}=$ cash flow from operations in $t-1$.

$C F O_{t}=$ cash flow from operations in $t$.

$C F O_{t+1}=$ cash flow from operations in $t+1$.

$\triangle R E V_{t}=$ change in operating revenue from $t-1$ to $t$.

$P P E_{t}=$ Property Plant and Equipment reported at $t$.

$\varepsilon_{t}=$ accruals quality (residual).

All variables are scaled by average total assets.

Cash flows are winsorised at 1 and 99 percentiles. 
Table 4

Regression results -accruals quality and innate characteristics Panel A $(n=519)$ DD model

\begin{tabular}{|c|c|c|c|}
\hline & Coefficient & $t$-statistic & $p$ value \\
\hline Int. & 0.448 & 6.549 & 0.000 \\
\hline SIZE & -0.019 & -5.934 & 0.000 \\
\hline LOSS & 0.014 & 2.727 & 0.007 \\
\hline OPCYC & -0.005 & -0.931 & 0.352 \\
\hline SDOR & 0.038 & 2.649 & 0.008 \\
\hline Adj. $R^{2}$ & 0.185 & & \\
\hline \multicolumn{4}{|c|}{ Panel B $(n=519)$ McNichols model } \\
\hline & Coefficient & $t$-statistic & $p$ value \\
\hline Int. & 0.445 & 6.660 & 0.000 \\
\hline SIZE & -0.019 & -6.083 & 0.000 \\
\hline LOSS & 0.013 & 2.548 & 0.011 \\
\hline OPCYC & -0.004 & -0.663 & 0.508 \\
\hline SDOR & 0.034 & 2.426 & 0.016 \\
\hline Adj. $R^{2}$ & 0.182 & & \\
\hline \multicolumn{4}{|c|}{$\begin{array}{l}\text { SIZE = Natural log of total assets at } 2004 . \\
\text { LOSS = Number of years in which a loss was recorded for } 2002 \text { to } 2004 . \\
\text { OPCYC = Natural log of average age of inventory plus the average age of receivables (in } \\
\text { days) } 2003 \text { and } 2004 \text { after winsorising at } 365 \text { days. } \\
\text { SDOR }=\text { Standard deviation of operating revenue divided by total assets for } 2001 \text { to } 2005\end{array}$} \\
\hline
\end{tabular}


Table 5

Regression - governance and discretionary accruals quality $(\mathrm{n}=392)$

Panel A: Regression - McNichols model

Model 1

(Equation 4)
Model 2

(Equation 5)

\begin{tabular}{rcrrlrrr}
\hline Variable & $\begin{array}{c}\text { Predicted } \\
\text { Sign }\end{array}$ & Coefficient & $t$-statistic & $p$ & Coefficient & $\begin{array}{c}t \text { - } \\
\text { statistic }\end{array}$ & $p$ \\
\hline Constant & & 0.139 & 5.598 & 0.000 & 0.080 & 6.286 & 0.000 \\
PROIND & - & 0.023 & 1.044 & 0.149 & 0.006 & 0.306 & 0.380 \\
DUAL & + & -0.003 & -0.202 & 0.420 & 0.002 & 0.123 & 0.450 \\
ACBP & - & & & & -0.001 & -0.082 & 0.935 \\
NDIRAC & - & -0.012 & -2.263 & 0.012 & & & \\
PROINDAC & - & -0.027 & -1.273 & 0.100 & & & \\
MEETAC & - & -0.003 & -1.313 & 0.095 & & & \\
PROEXP & - & -0.007 & -0.435 & 0.664 & & & \\
AUDITOR & - & -0.020 & -2.008 & 0.023 & -0.028 & -2.850 & 0.005 \\
Adj. ${ }^{2}$ & & 0.028 & & & 0.012 & & \\
\hline
\end{tabular}

Panel B: Regression - DD model

Model 1

(Equation 4)
Model 2

(Equation 5)

\begin{tabular}{rcrrlrrr}
\hline Variable & $\begin{array}{c}\text { Predicted } \\
\text { Sign }\end{array}$ & Coefficient & $t$-statistic & $p$ & Coefficient & $t$-statistic & $p$ \\
\hline Constant & & 0.136 & 5.450 & 0.000 & 0.078 & 6.125 & 0.000 \\
PROIND & - & 0.025 & 1.128 & 0.130 & 0.009 & 0.423 & 0.486 \\
DUAL & + & -0.004 & -0.248 & 0.404 & 0.001 & 0.071 & 0.470 \\
ACBP & - & & & & -0.002 & -0.158 & 0.436 \\
NDIRAC & - & -0.012 & -2.168 & 0.015 & & & \\
PROINDAC & - & -0.030 & -1.414 & 0.076 & & & \\
MEETAC & - & -0.003 & -0.992 & 0.166 & & & \\
PROEXP & - & -0.006 & -0.353 & 0.362 & & & \\
AUDITOR & - & -0.017 & -1.748 & 0.040 & -0.025 & -2.531 & 0.006 \\
Adj. ${ }^{2}$ & & 0.021 & & & 0.010 & & \\
\hline
\end{tabular}

PROIND = Number of independent directors divided by the number of directors.

DUAL = Dummy, coded 1 if CEO is chair of board of directors, coded 0 otherwise .

ACBP = Dummy, coded 1 for committees that are wholly comprised of independent and non-executive directors; have three or more directors assigned; meet at least as frequently as the sample mean; and, have one committee member with professional accounting qualifications. Coded 0 otherwise.

NDIRAC $=$ Number of directors on the audit committee.

PROINDAC $=$ Proportion of independent directors on the audit committee.

MEETAC $=$ Number of audit committee meetings each year.

$P R O E X P=$ Number of audit committee members with professional accounting qualifications divided by the number of committee members.

AUDITOR = Dummy, coded 1 if appointed auditor is one of the Big 4 firms. 
Table 6: Regression - Governance and Innate Accruals Quality $(\mathrm{n}=392)$

Panel A: Regression - McNichols model

\begin{tabular}{rcrllrrr}
\hline & & \multicolumn{2}{c}{$\begin{array}{c}\text { Model 3 } \\
\text { (Equation 6) }\end{array}$} & \multicolumn{4}{c}{$\begin{array}{c}\text { Model 4 } \\
\text { (Equation 7) }\end{array}$} \\
\hline Variable & $\begin{array}{c}\text { Predicted } \\
\text { Sign }\end{array}$ & Coefficient & t-statistic & $p$ & Coefficient & $t$-statistic & $p$ \\
Constant & & 0.215 & 17.450 & 0.000 & 0.141 & 21.039 & 0.000 \\
PROIND & + & -0.002 & -0.187 & 0.426 & -0.017 & -1.534 & 0.063 \\
DUAL & + & 0.013 & 1.688 & 0.046 & 0.017 & 2.086 & 0.019 \\
ACBP & - & & & & -0.025 & -4.124 & 0.000 \\
NDIRAC & - & -0.016 & -6.008 & 0.000 & & & \\
PROINDAC & - & -0.022 & -2.111 & 0.017 & & & \\
MEETAC & - & -0.007 & -5.376 & 0.000 & & & \\
PROEXP & - & -0.005 & -0.595 & 0.276 & & & \\
AUDITOR & - & -0.031 & -6.229 & 0.000 & -0.038 & -7.463 & 0.000 \\
Adj. R ${ }^{2}$ & & 0.319 & & & 0.214 & & \\
\hline
\end{tabular}

Panel B: Regression - DD model

Model 3

(Equation 6)
Model 4

(Equation 7)

\begin{tabular}{rcrrlrrr}
\hline Variable & $\begin{array}{c}\text { Predicted } \\
\text { Sign }\end{array}$ & Coefficient & $t$-statistic & $p$ & Coefficient & -statistic & $p$ \\
\hline Constant & & 0.217 & 16.784 & 0.000 & 0.142 & 20.326 & 0.000 \\
PROIND & + & 0.001 & 0.110 & 0.456 & -0.015 & -1.281 & 0.100 \\
DUAL & + & 0.012 & 1.536 & 0.062 & 0.016 & 1.939 & 0.026 \\
ACBP & - & & & & -0.026 & -4.100 & 0.000 \\
NDIRAC & - & 0.016 & -5.735 & 0.000 & & & \\
PROINDAC & - & -0.025 & -2.312 & 0.010 & & & \\
MEETAC & - & -0.007 & -5.183 & 0.000 & & & \\
PROEXP & - & -0.003 & -0.393 & 0.347 & & & \\
AUDITOR & - & -0.032 & -6.327 & 0.000 & -0.040 & -7.628 & 0.000 \\
Adj. ${ }^{2}$ & & 0.304 & & & 0.214 & & \\
\hline
\end{tabular}

PROIND = Number of independent directors divided by the number of directors.

$D U A L=$ Dummy, coded 1 if CEO is chair of board of directors, coded 0 otherwise.

ACBP = Dummy, coded 1 for committees that are wholly comprised of independent and non-executive directors; have three or more directors assigned; meet at least as frequently as the sample mean; and, have one committee member with professional accounting qualifications. Coded 0 otherwise.

NDIRAC $=$ Number of directors on the audit committee.

PROINDAC $=$ Proportion of independent directors on the audit committee.

MEETAC = Number of audit committee meetings each year .

PROEXP = Number of audit committee members with professional accounting qualifications divided by the number of committee members.

AUDITOR = Dummy, coded 1 if appointed auditor is one of the Big 4 firms. 
Table 7: Additional Analyses - CFO Proxy Test

\begin{tabular}{rcrrrrrrr}
\hline & \multicolumn{3}{c}{ DAQ $(n=392)$} & \multicolumn{5}{c}{ IAQ $(n=392)$} \\
\hline Variable & $\begin{array}{c}\text { Predicted } \\
\text { Sign }\end{array}$ & Coefficient & $\begin{array}{c}t- \\
\text { statistic }\end{array}$ & $p$ & $\begin{array}{c}\text { Predicted } \\
\text { Sign }\end{array}$ & Coefficient & $\begin{array}{c}t- \\
\text { statistic }\end{array}$ & $p$ \\
\hline Constant & & 0.188 & 4.175 & 0.000 & & 0.221 & 15.543 & 0.000 \\
PROIND & - & -0.070 & -1.746 & 0.041 & + & -0.003 & -0.200 & 0.421 \\
DUAL & + & 0.000 & 0.017 & 0.497 & + & 0.014 & 1.571 & 0.058 \\
NDIRAC & - & -0.016 & -1.589 & 0.056 & - & -0.017 & -5.507 & 0.000 \\
PROINDAC & - & 0.011 & -1.578 & 0.366 & - & -0.022 & -1.815 & 0.035 \\
MEETAC & - & -0.007 & -1.185 & 0.057 & - & -0.007 & -4.472 & 0.000 \\
PROEXP & - & -0.035 & 0.290 & 0.118 & - & -0.005 & -0.531 & 0.297 \\
AUDITOR & - & -0.011 & -0.590 & 0.278 & - & -0.033 & -5.905 & 0.000 \\
Adj. ${ }^{2}$ & 0.019 & & & & 0.274 & & & \\
\hline
\end{tabular}

PROIND = Number of independent directors divided by the number of directors.

$D U A L=$ Dummy, coded 1 if CEO is chair of board of directors, coded 0 otherwise.

NDIRAC = Number of directors on the audit committee.

PROINDAC $=$ Proportion of independent directors on the audit committee .

MEETAC = Number of audit committee meetings each year .

PROEXP = Number of audit committee members with professional accounting qualifications divided by the number of committee members.

AUDITOR = Dummy, coded 1 if appointed auditor is one of the Big 4 firms. 


\section{References}

Aboody, D., J. Hughes, and J. Liu, 2005, Earnings quality, insider trading, and cost of capital, Journal of Accounting Research 43, 651-673.

Ashbaugh-Skaife, H., D. W. Collins, and R. LaFond, 2006, The effects of corporate governance on firms' credit ratings, Journal of Accounting and Economics 42, 203-243.

Ashbaugh-Skaife, H., D. W. Collins, W.R. Kinney, and R. LaFond, 2007, The effect of SOX internal control deficiencies and their remediation on accruals quality, Working Paper, Available at http://ssrn.com/abstract=906474.

Austin, L. M., and M. E. Bradbury, 1995, The accuracy of cash flow estimation procedures, Accounting and Finance 35, 73-86.

Australian Securities Exchange (ASX), 2007, Corporate Governance Council, Corporate governance principles and recommendations, $2^{\text {nd }}$ edition, ASX, Sydney.

Bartov, E., F.A. Gul, and J.S.L. Tsui, 2000, Discretionary accruals models and audit qualifications, Journal of Accounting and Economics 30, 421-452.

Becker, C., M. DeFond, J. Jiambalvo, and K. R. Subramanyam, 1998, The effect of audit on the quality of earnings management, Contemporary Accounting Research 15, 1-24.

Beekes, W., and P. Brown, 2006, Do better-governed Australian firms make more informative disclosures? Journal of Business Finance \& Accounting 33, 422-450.

Biddle, G. C. and G. Hilary, 2006, Accounting quality and firm-level capital investment, The Accounting Review, 81, 963-982.

Blue Ribbon Committee, 1999, Report and Recommendations of the Blue Ribbon Committee on Improving the Effectiveness of Corporate Audit Committees (NYSE, New York).

Cadbury Report, 1992, Report of the Committee on the Financial Aspects of Corporate Governance, Chaired by Sir Adrian Cadbury (Burgess Science Press: London).

Chen, S., T. Shevlin, and Y.H. Tong, 2007, Does the pricing of financial reporting quality change around dividend changes? Journal of Accounting Research 45, 1-40.

Cohen, J., G. Krishnamoorthy, and A. Wright, 2002, Corporate governance and the audit process, Contemporary Accounting Research 19, 573-592.

Collier, P.A., 1993, Audit committees in major U.K. companies, Managerial Auditing Journal 8, 25-30.

Davidson, R., J. Goodwin-Stewart, and P. Kent, 2005, Internal governance structures and earnings management, Accounting and Finance 45, 241-267.

DeAngelo, L.E., 1981, Auditor independence, "low-balling” and disclosure regulation, Journal of Accounting and Economics 3, 113-127. 
Dechow, P.M., 1994, Accounting earnings and cash flows as measures of firm performance: the role of accounting accruals, Journal of Accounting and Economics 18, 3-42.

Dechow, P.M., R.G. Sloan, and A. P. Sweeney, 1995, Detecting earnings management, The Accounting Review 70, 193-225.

Dechow, P.M., R.G. Sloan, and A. P. Sweeney, 1996, Causes and consequences of earnings manipulation: An analysis of firms subject to enforcement by the SEC, Contemporary Accounting Research 13, 1-36.

Dechow, P., and I. Dichev, 2002, The quality of accruals and earnings: the role of accruals estimation errors, The Accounting Review, Supplement 77, 35-59.

DeZoort, F.T., D.R. Hermanson, D.S. Archambeault, and S.A. Reed, 2002, Audit committee effectiveness: A synthesis of the empirical audit committee literature, Journal of Accounting Literature 21, 38-75.

DeZoort, F. T., and S. Salterio, 2001, The effects of corporate governance experience, financial reporting and audit knowledge on audit committee members' judgments, Auditing: A Journal of Practice \& Theory 20, 31-47.

Donaldson, L., 1990, The Ethereal Hand: Organizational Economics and Management Theory, Academy of Management Review 15, 369-381.

Donaldson, L., and J.H. Davis, 1991, Stewardship theory or agency theory: Corporate governance and shareholder returns, Australian Journal of Management 16, 49-64.

Donaldson, L., and J.H. Davis, 1994, Boards and Company Performance - Research Challenges the Conventional Wisdom, Corporate Governance: An International Review 2, 151-160.

Doyle, J., W. Ge, and S. McVay, 2007, Accruals quality and internal control over financial reporting, The Accounting Review 82, 1141-1170.

Fama, E. F., and M. Jensen, 1983, Separation of ownership and control, Journal of Law and Economics 26, 301-325.

Farber, D. 2005, Restoring trust after fraud: Does corporate governance matter? The Accounting Review 80, 539-561.

Francis, J., R. LaFond, P.M. Olsson, and K. Schipper, 2004, Costs of equity and earnings attributes, The Accounting Review 79, 967-1010.

Francis, J., R. LaFond, P.M. Olsson, and K. Schipper, 2005, The market pricing of accruals quality, Journal of Accounting and Economics 39, 295-327.

Francis, J. R., E. L. Maydew, and H. C. Sparks, 1999, The role of Big 6 auditors in the credible reporting of accruals, Auditing: A Journal of Practice \& Theory 18, 17-34. 
Hughes, R., 1999, The rise and rise of the audit committee, Accountancy 123, February, 59.

Jiambalvo, J. 1996, Discussion of causes and consequences of earnings manipulation: An analysis of firms subject to enforcement by the SEC, Contemporary Accounting Research 13, 37-47.

Jones, J., 1991, Earnings management during import relief investigations, Journal of Accounting Research 29, 193-228.

Kalbers, L.P., and T. J. Fogarty, 1993, Audit committee effectiveness: An empirical investigation of the contribution of power, Auditing: A Journal of Practice and Theory 12, 24-49.

Karamanou, I., and N. Vafeas, 2005, The association between corporate boards, audit committees, and management earnings forecasts; an empirical analysis, Journal of Accounting Research 43, 453-486.

Kent, P., and J. Stewart, 2008, Corporate Governance and the Disclosure by Australian Companies of the Impact of International Financial Reporting Standards, 2008, Accounting and Finance, 48, 649-671.

Kiel, G.C., and G.J. Nicholson, 2003, Board composition and corporate performance: how the Australian experience informs contrasting theories of corporate governance, Corporate Governance: An International Review 11, 189-205.

Kim, J.B., R. Chung, and M. Firth, 2003, Auditor conservatism, asymmetric monitoring, and earnings management, Contemporary Accounting Research 20, 323-359.

Klein, A, 2002, Audit committee, board of director characteristics, and earnings management, Journal of Accounting and Economics 33, 375-400.

Knapp, M., 1987, An empirical study of audit committee support for auditors involved in technical disputes with client management, The Accounting Review 62, 578-588.

Koh, P.S., S.K. LaPlante, and Y.H Tong, 2007, Accountability and value enhancement roles of corporate governance, Accounting and Finance 47, 305-333.

Krishnan, J., 2005, Audit committee quality and internal control: an empirical analysis, The Accounting Review 80, 649-675.

McMullen, D. A., and K. Raghunandan, 1996, Enhancing audit committee effectiveness, Journal of Accountancy 182, 79-81.

McNichols, M.F., 2000, Research design issues in earnings management studies, Journal of Accounting and Public Policy 19, 313-345.

McNichols, M.F., 2002, Discussion of: the quality of accruals and earnings: the role of accruals estimation errors, The Accounting Review, Supplement 77, 61-69. 
Nicholson, G.J., and G.C. Kiel, 2007, Can Directors Impact Performance? A case-based test of three theories of corporate governance, Corporate Governance: An International Review $15,585-608$.

NYSE and NASD, 1999, Report and recommendations of the Blue Ribbon Committee on improving the effectiveness of corporate audit committees. New York Stock Exchange and National Association of Securities Dealers, http://www.kpmg.com/aci/docs/blueribbon.pdf.

Raghunandan, K., W.J. Read, and D.V. Rama, 2001, Audit committee composition, "gray directors”, and interaction with internal auditing, Accounting Horizons 15, 105-118.

Rainsbury, E.A., M.E. Bradbury, and S.F. Cahan, 2008, Firm characteristics and audit committees complying with 'best practice' membership guidelines, Accounting and Business Research 38, 393-408.

Richardson, S.A., R.G. Sloan, M.T. Soliman, and I. Tuna, 2005, Accrual reliability, earnings persistence and stock prices, Journal of Accounting and Economics 39, 437-485.

Schipper, K., and L. Vincent, 2003, Earnings quality, Accounting Horizons, Supplement, 97110.

Srinidhi, B., and F.A. Gul, 2007, The differential effects of auditors' non-audit and audit fees on accruals quality, Contemporary Accounting Research 24, 595-629.

Standards Australia International, 2003, AS 8000 - 2003, Australian standard - good governance principles, Standards Australia International, Sydney.

Tabachnick, B.G., and L.S. Fidell, 1996, Using multivariate statistics (HarperCollins, New York).

Wolnizer, P.W., 1995, Are audit committees red herrings? Abacus, 31, 45-66. 